\title{
Harmony and balance between the orient and the occident in the woman warrior
}

\author{
Zhang Qiang \\ School of Foreign Languages, Shandong Jiaotong University, Jinan, China
}

Email address:

To cite this article:

Zhang Qiang. Harmony and Balance between the Orient and the Occident in the Woman Warrior. International Journal of Literature and Arts. Vol. 2, No. 3, 2014, pp. 60-64. doi: 10.11648/j.ijla.20140203.11

\begin{abstract}
Maxine Hong Kingston is one of the most famous female Chinese American writers in 20th century. Her famous novel The Woman Warrior confirmed her status in American literature. The novel describes the heroine's life as a Chinese American and depicts the psychological course and conflict when confronting the pressure from both gender and culture. This book indicates Kingston's pursuit of the harmony and balance in a variety of aspects. This paper mainly focuses on the harmony and balance between East and West. The first part deals with the theme of mother and daughter's relation, in which the mother represents the traditional Chinese culture while the daughter struggles among the conflicts of eastern and western culture. Secondly, the novel conveys the ethnic women's appeal by talking about the texts of the novel. The author also reveals the Chinese Americans' pursuit of self-identity. Kingston was writing with an intense aspiration of speaking for the Chinese. The third part is the theme of silence and articulation in which Kingston tries to reconstruct their identity by breaking up the silence and articulating their appeal. Kingston also put forward a dream of globalization and unity in her novel.
\end{abstract}

Keywords: The Woman Warrior, Chinese American, Harmony and Balance, Identity

\section{Introduction}

It is generally acknowledged that Maxine Hong Kingston is one of the Chinese American writers who had gained great reputation for both novels and fictions. Through the vivid description of her Chinese forefather and the struggle of Chinese immigrating to the US, she demonstrates the Chinese Amricans' life to the reads all around the world. There is no doubt that Kingston is one of the famous female Chinese American writers in 20th century. The novel The Woman Warrior is her most successful work and has confirmed her status in American literature. In this novel, the author illustrated the second-generation Chinese American women's struggle among the American culture in which they grow up and the Chinese culture which their fathers and mothers try to impose on them. Therefore, these women are longing for their recognition as the mainstream of the American society, while they feel that it is difficult for them to get rid of their Chinese identity. The Woman Warrior demonstrates the culture shock among the ChineseAmerican mothers and daughters and tries to explain the reason why the second-generation of Chinese-Americans are isolated by the American society and the patriarchal
Chinese community. Although there is social and sexual prejudice for these Chinese-American daughters, they ultimately withstand their cross-cultural status and succeeded in establishing their own identity.

The novel illustrates the heroine's life in a ChineseAmerican family and then reveals her mental process during her growing up. This process is described as a process from the heroine's illusion on her avenge to her rebellion, and ultimately to a chase for a harmonious relationship and a mutual trust between the culture and gender. The novel vividly described the struggle and exploration of ChineseAmericans in the process of building up their identity in the overlay between China and America.

\section{Theme of Mother and Daughter}

When she refers to the origin of the poet Ts'ai Yen's Song for a Barbarian Reed Pipe, the narrator of The Woman Warrior becomes to know that she has the lineage of her mother's genius. Her ability of reading and writing the stories in her family is inherited from her mother's dialogic skills, and the dynamic interplay of the conversational and literary voice in intertextuality connects mother and 
daughter as surely as the ties of blood. The beginning is her mother's story, while the ending is the daughter narrator's.

A woman from Hong family first stated the stories orally; and Ah Goong proposed a crucial "outset" for her mother. Definitely, his Tales of a Gold Mountain is a significant origin of Brave as a narrator. Ts'ai Yen might have left behind Eighteen Stanzas for a Barbarian Reed Pipe, and despite the fact that the words she sang cannot be understood by the children and captors who was born in other countries, her voice has expressed "sadness and anger" of a Chinese woman who was on banishment. This novel reestablishes the history of the immigration of Chinese to America and obscures the boundary of autobiography. And the novel also provides a figure who was a brave survivor to pass through the pressure of sex and race. Then the mother has become the sample for the author to reconcile the different lives of Chinese-American women or girls. The Chinese women authors rebuilt the identity and the migration history of the Chinese-American women, and then found the concealed fact behind the mainstream society.

Taken as a starting point her experiences as a firstgeneration Chinese-American girl growing up in California before World War II, Kingston demonstrated the readers a totally different world of her Chinese parents-folk stories, legends, traditions and customs in China. In this novel, she expressed her pain as an American-born Chinese girl who unavoidably denies the anticipation and authority of the Chinese family that support the values of America and the pain of her own ties to her mother who was a survivor and a woman of tremendous energy and power. The author scratches the conflict and struggle which implant a complicated mother and daughter relationship in a poetic and original style.

Kingston also handled the American dream as the theme in the novel and denied by the culture conflict between orient and occident, as proclaimed by the conflicts between the two generations of Chinese. The distinct culture lineage of orient and occident, the diverse comprehension of survival and the social position in China and America are the main reasons of the mother and daughter's conflict in this novel. These reasons can be treated as the origin of the conflicts between generations and nations.

In the novel Woman Warrior, the relationship between the heroine and her mother is a mainline of the story, furthermore, there are issues of cultural diversity, the identities and the boundary of exchange between two generations play a vital role of propelling the plot by exploring the memories. The writer had successfully depicted the history of mother and the author herself in an immigrant Chinese family by intersecting the image, memory and fact together. On the surface, this novel looks as if the autobiography of the author herself and a track of a family fighting for their lives in a totally different country. And this novel is not just a description of the intense relationship between the author and her mother, but also a depiction on the hundreds of thousands Chinese mothers who were attempting to survive in America. The novel is a recollection of the relation between China and America; moreover, it also implies the author's sincere expectation for the friendly relation of between the two countries.

\section{The Pursuit of Self-Identity and Ethnic Women's Appeal}

The novel concerns the ethnic women's appeal to a large extent. Kingston was writing this novel with an intense feeling of mission in supporting the Chinese American women's appeal. The ultimate aim of this novel is to deconstruct the western logo centrism and reconstruct the history and identity of the Chinese immigrants into the mainstream of American society. Kingston expected that the relation between China and US will be more harmonious and balanced.

People in each country do have their unique expressions of sadness and happiness. These expressions could only be understood when given in a particular culture or circumstance. When people migrate to other countries, they might be the persons who are affected by the new culture and custom of the new country; after a period of time, they may find that it is difficult for them to share their feelings with those who remain in their original countries.

Kingston's childhood and school life was not so happy then. Because she was uncertain of her oral English, she said that: "During the first silent year, I spoke to no one at school, did not ask before going to the lavatory, and flunked kindergarten...it did not occur to me I was supposed to talk.'(Kingston, 1976:165-66) In her early school days, she was a sufferer rather than a resister: children from Japan kick her; she and other Chinese girls were refused to attend the play. When she reaches sixth grade old, she regarded herself as "was arrogant with talk". (Kingston, 1976:173) She gradually became a top level student and actively participated in clubs and finally got a scholarship to a university. But due to her attempts to adjust to the American education system successfully, Kingston did not intend to reverse the system. Her revolt was mainly expressed in overcome the difficulties lay in her own culture which decelerated her step to the top.

One of the key issues in this novel is the author's own identification of her profession as a writer with that of the woman warrior, which she attempted to render the Chinese traditional lineage into the current occident terminology. It looks like to bridge the difference that separates Chinese traditional culture and western cultures. One issue which Kingston was always highlighting in her novel is the incidental parallels and analogy between Chinese and English. When this issue was being used in assimilating the two different cultures, Kingston's use of wordplay is becoming more interesting. For example when she complained about the figurative "dilemma" that "China still wraps her feet" (Kingston, 1976:48), or when the author's father called a gypsy woman who had just cheated 
him a "gypsy bag" for the meaning of "smelly pig-bag". (Kingston, 1976:48) Except the puns that practically functioned between different languages and cultures, there are still others which are confined to a particular language, but play a vital role in rendering one culture to another, alleviating the strain that separates the author's Chinese lineage from the American culture.

It seems not reasonable to look Kingston's novel from an isolated aspect, because her works are so intertextual that can combine China and America as well as orient and occident together. The two concepts cannot be isolated and should be connected closely with each other. Currently, some people are worrying so much about the cultural assimilation and fearing of losing their own cultural identity. They are so jealous of their myths, but in fact all the myths are the treasure of all human-beings. Marginalized groups have little contribution to the concepts of uniformity, consistency and generality since their own political efficacy lies in imposing the different values on the mainstream culture. In this novel, the heroine was trying hard to express her own viewpoint. She had got the strength and the bravery to carry on her "pressed duck" appeal and sustain her own voice.

An effective way the author attempted to write to help the integration of China and US was to implant the Chinese traditions and folk stories into the American context. By contrast with Frank's rage and criticism to the advocate of integrating Chinese and American identity, Kingston has showed a moderate and soft attitude. The most critical procedure to self-affirmation for people who are under compression was to destroy the silence which was imposed on them and to discover the right appeal. This paper has witnessed how the author played with Chinese traditional stories and classics, and uncovered how she has developed a brand-new identity.

For a minority from another country, the physical appearance which distinguishes her from the Americans, and establishes the most direct impression for other people, was the image that cannot be changed. The sense of "otherness" was a common sense that most Chinese Americans must confront and endure. The famous doctrine Origin of Species which was proposed by Darwin might be considered as a symbol in the ethnology of the Victorians, while but "articulated views about the difference between 'our own kind' and the people of other cultures" have been around "almost as far back as the earliest human writing" (Kingston, 1976:20). Why there are different attitudes among different groups of people, except for the clear differences in biological appearance and skin color? Basing on the racial doctrine, the answer could be concluded as blood lineage. Many racists think the human-beings can be divided into various groups, which can be called "races", and every member in the group will have common and important features. Moreover, racists propose that the essence of the race occupies more than the apparent visible features such as the color of hair and skin. Saying a person who is "yellow" does not only mean that he or she has a yellow face or a flat nose, it also indicates some other crucial features which are the lineage of this race, for example, silence, intelligence and diligence. Racial theorization has prompted all kinds of stereotypes concerning the races. But racial theorization does not account for the reason why the figures of the "yellow face" always contain negative meanings, only if surveys on the formation of racial divergences are fulfilled. It is no doubt that in America people from China are always stereotyped as rude and cunning, with Chinese males being feminine and Chinese females being sophisticated and tame.

Therefore, a term which was proposed by Edward called "Orientalism" was used as the stereotype of Chinese Americans. The term Orientalism could be explained as " $a$ style of thought based upon an ontological and epistemological distinction made between 'the Orient' and (almost of the time) 'the Occident." (from www.english.emory.edu) Furthermore, this term has pointed out that "the Orient has helped to define Europe (or the West) as its contrasting image, idea, personality, experience." (from www.english.emory.edu) Except for only making a comparison, "the idea of European identity" is "a superior one in comparison with all the non-European peoples and cultures." (from www.english.emory.edu) One of the risks of stereotyping is the deformation which was produced by dogmatic generalization. People's identity, which needs the inward feature and uniqueness, strongly opposes such generalization. If a person wants to find and rebuild his or her own identity, he or she must destroy the basis of the original stereotype which was naturally imposed on him or her with social elements. On the way to find their own identity, the Chinese Americans have to confront a very difficult boundary, that is, the racial stereotype about Chinese in America mainstream culture. Maybe more white people know Fu Manchu, but few of them know the real Chinese Americans. It could not only avoid the Chinese children in America to know the real Chinese figures, but also make the Chinese Americans to develop a sense of self-contempt because the images of Chinese are so ugly. Some comics concerning Chinese people are very popular in American culture for many years, in these comics, the image of Chinese are also very humble and ugly. The racial stereotypes and comics of Chinese can also appear in some famous writers' works such as Mark Twain. These works had also contributed to the formation of the ugly stereotypes of Chinese.

Universally speaking, the stereotype of Chinese could be divided into two basic categories in American literature: the "evil" Chinese and the "kind" Chinese. The "evil" Chinese refer to the figures such as sinister villains and Fu Manchu, both of them could not be controlled and so they must be extinguished. A representative of this image is Fu Manchu who is very clever, but he used his wisdom to achieve his evil purposes. Another type of Chinese stereotype is the "kind" Chinese, referring to the poor heathens and the loyal servants and "model minority", who is a new figure of the "kind" Chinese, was always obeying the rules of the white 
world and support the law and regulation. Afterwards, there appeared a new image called Charlie Chan, people created him as a substitute for the image of $\mathrm{Fu}$ Manchu. He is an intelligent, smiling, pudgy symbol of the sagacity and charm of Chinese. There is public's acquaintance and approval of him as a non-risk, non-sexual and woman-like white. Inferior for a long time, the "kind" Chinese could be integrated into American mainstream. Balancing the "evil" Chinese Fu, who was the establishment of "racist hatred", "kind" Chinese like Charlie could be regarded as the outcome of "racist affection", and it indicates that the Chinese Americans are obedient. We should pay attention to one point that in both images of "evil" and "kind", the description of them could only function as a foil to depict the American as "non-Chinese". In the works that describe Chinese as "evil", the Americans are depicted as full of humanity in an indirect way; when the Chinese are described as "kind", the work mainly aims to demonstrate the white American's importance and kindness. The white heroes in Fu Manchu novels are righteous and could never be beaten by the inhuman $\mathrm{Fu}$ Manchu. The intelligent Charlie Chan resolved many mysteries for his white friends and clients. The implacable and long-term differences between Americans and Chinese, and the belief of Chinese as the "different", are the mutual thread running through the portrayals. Therefore, a Chinese American author's responsibility is to make contributions to the figure and identity of Chinese Americans by means of revealing the discriminations and inequality, and then reconstruct a new and positive image for Chinese Americans.

\section{Theme of Silence and Articulation}

As for someone who is under double compression, the reconstructing of his or her own identity is, most importantly, to articulate his or her own voice. In the novel The Woman Warrior, the common thread lies in the theme of silence and articulation. During the process of her writing, Kinston made records for her pains and fights for a distinctive voice. In this novel, the matter of voice and silence is the center of the two stories of the heroine's female relatives which haunt her most: the tales of her no name aunt in China. The tale of the "nameless aunt" is a tale of public disgrace which contains the plot of the aunt's adulterous pregnancy and suicide, and the mother told the daughter this story in a shocking effect, warning her not to tell the tale to others. At the beginning of the novel, the mother warned the daughter not to tell anyone about the tale that his father's sister had killed herself by jumping into the well. It is said that his father only has brothers because his sister seems as if never been born. Silence in this part functions as a severe punishment. Giving someone a name is a way of acknowledge his or her identity. So in this chapter, the title "No-Name Woman" indicates that the members in the family intently wiped her away from the history of the family. The tale of moon orchid is in the chapter "At the Western Palace". It is a tragicomic story of the mother. The hero Brave's oppression on her sister is serious and she tries to impose alienation and finally lead to his sister's madness. It is an old tale in a new environment for the heroine, as she could not resolve her experiences in California. It is a feature that the symptom of her madness is her repetition of the identical story. From Maxine's perspective, the same tale is the equivalent of silence.

"One night when the laundry was so busy that the whole family was eating dinner there, crowded around the little round table, my throat burst open. I stood up, talking and burbling. I looked directly at my mother and at my father and screamed, 'I may be ugly and clumsy, but one thing I am not, I am not retarded. Not everybody thinks I am nothing...I'm getting out of here. I can't stand living here anymore. You're your fault I talk weird. And I don't want to listen to any more of your stories; they have no logic. They scramble me up. You lie with your stories. You won't tell me a story and then say this is a true story or this is just a story. I can't tell the difference. I don't even know what your real names are. 1 can't tell what's real and what you make up. You can't stop me from talking. You tried to cut my tongue, but it didn't work."'(Kingston, 1976: 77) The torrent of these words was a way of terminating the silence and its madness. Articulation is not just a way for the young girl to achieve her own identity, but also a way to confirm the identity of the Chinese who live in America. Kingston has made the authority of her words become the muted communal tales which exceeded her individual self.

Kingston also indicated that silence is not a distinction of the Chinese Americans; it is the racists who imposed this distinction on Chinese. Except for this chapter, nevertheless, the author did not focus on the feminization of Chinese men. While instead, Kingston paid her attention to the narration on Chinese men's rebellions, notable deeds and their accomplishments. In this novel, discourse, language and tales are the carriers of Chinese identity and history.

The combination of silence and articulation also indicated Kingston's attempts to eliminate the barrier among various races, and appeal to people of different forefathers to cooperate and play on the same stage. The concept of "play" is very significant, and it includes at least 3 connotations: a) "play" is a symbol of culture; b) to "play" a piece of musical instrument means to link the gap among people from different culture or countries because music attracts people all over the world; c) "playfulness" is the author's naughty character, which indicates her peaceful trend in conceding the conflicts between the mainstream white culture and the minority culture. Her pacifist concept first emerged in Yen's tales, where she intently changed the original tune into a more peaceful picture. In the story, the barbarians heard a song which was sung by a lady, the voice is clear and the high-pitched. The words sounds like Chinese, but the barbarians could feel the sadness and anger in it. In both voice and images, this passage has established a scene of mystery, "crossing boundaries not delineated in space" and surpassing differences in words. Kingston acknowledged that: "I do believe in the 
timelessness and universality of individual vision. The Woman Warrior would not just be a family book or an American book or a woman's book, but a world book, and at the same moment, my book." (Skenazy, Paul, and Martin, era. eds, 1998:107) From the above we can clearly conclude that Kingston's dream was to realize the globalization and unity of the world. Comparing herself to the famous female warrior in China called Hua Mulan, Kingston attempts to use her words as the sword to fight for a new identity for Chinese living in the America.

\section{Conclusion}

The major theme of this novel is a reflection of the Chinese Americans' fight for the establishment of their own identity, we can even say it is a fighting history for Chinese culture. They are longing for the culture of their own forefather while they gradually integrate into the American culture. The Chinese Americans are the link between Chinese and American culture and play the role of reaching the balance and harmony between the two cultures. From the theme of daughter and mother, the novel also describes the differences and combination of the orient and occident culture. The mother is the representative of the traditional Chinese culture and takes care of her daughter in a particular way. Since the mother thinks that she is doing things for the good of her daughter, while the daughter does not show gratitude to her mother. The daughter could not understand what is important in her own mind. She adopts a strategy to resist her mother's requirements and does not anything her mother really expected. Actually, the daughter is fighting against the traditional culture and customs which was rooted deeply in her mother's mind. The final settlement of the conflict between mother and daughter is actually a representative of the tendency for the harmony and balance of the orient and occident culture and tradition. This reconciliation should be the way that Chinese American writers should explore. It indicates that the new generations of Chinese American could integrate Chinese and American culture and finally make them become complementary for each other. Thus the harmony and balance between Chinese and American culture could be finally accomplished.

\section{References}

[1] Abel, Elizabeth, Marianne Hirsch, and Elizabeth Langland, eds. The Voyage In: Fictions of Female Development. Hanover: UP of New England, 1983.

[2] Abrams, M. H. A Glossary of Literary Terms. 7th ed. Boston: Heinle, 1999.
[3] Allen, Graham. Intertextuality. London \& New York: Routledge, 2000.

[4] Buckley, Jerome Hamilton. Season of Youth: The Bildungsroman from Dickens to Golding. Cambridge, Massachusetts: Harvard UP, 1974.

[5] Chin, Frank et al. Aiiieeeee! An Anthology of Asian American Writers. Mentor Edition. New York: Pemguin Group, 1991.

[6] Clayton, Jay \& Rothstein, Eric. Influence and Intertextuality in Literary History. Wisconsin: The University of Wisconsin Press, 1991.

[7] Derrida, Jacque. Positions. Chicago: University of Chicago Press, 1982.

[8] E.D Huntely. Maxine Hong Kingston A Critical Companion. Greenwood Press, 2001.

[9] Feng, Pin-chia. The Female Bildungsroman by Toni Morrison and Maxine Hong Kingston: A Postmodern Reading. New York: Peter Lang, 1998.

[10] Fuderer, Laura Sue. The Female Bildungsroman in English: An Annotated Bibliography of Criticism. New York: The Modern Language America, 1990.

[11] Gao Yan. The Art of Parody: Maxine Hong Kingston's Use of Chinese Sources. New York: Peter Lang Publishing, Inc., 1996.

[12] Grice, Helena. Negotiating Identities: An Introduction to Asian American Women Writing. Manchester: Manchester UP, 2002.

[13] Helen Grice. Maxine Hong Kingston. Manchester: Manchester University Press 2006.

[14] Jaworski, Adam. The Power of Silence: Social and Pragmatic Perspectives. New York: Sage Publications Inc., 1993.

[15] Li, David LeiWei. Imaging the Nation-Asia American Literature and Cultural Consent. California: Stanford University Press, 1998.

[16] Lim, Shirley Geok-lin. "Growing with Stories': Chinese American Identities, Textual Identities.” Teaching American Ethnic Literatures: Nineteen Essays.

[17] Kingston Maxine Hong. The Woman Warrior--Memoirs of a Girlhood among Ghost. New York: Random House, 1977.

[18] Mandel, Barrett John. "The Autobiographer's Art". Journal of Aesthetics and Art Criticism 27 (Winter 1968).

[19] Maureen Sabine. Maxine Hong Kingston's Broken Book of Life: An Intertextual Study of The Woman Warrior and China Men HONOLULU: University of Hawaii Press, 2004.

[20] Plett, H. Intertextuality (Research in Text Theory). Berlin: de Gruyter, 1991. 